\title{
O PADRE ANTÔNIO VIEIRA E O MÉTODO DA PREGAÇÃO
}

\section{The preaching methods of Father Antônio Vieira}

\section{Márcio Luiz Fernandes}

Doutor em Psicologia pela Universidade de São Paulo (USP), Mestre e Doutorando em Teologia Fundamental pela Pontifícia Universidade Lateranense, professor de Teologia no Studium Theologicum e no Programa de Pós-Graduação em Teologia da Pontifícia Universidade Católica do Paraná (PUCPR), Curitiba, PR - Brasil, e-mail: marciovisconde@yahoo.com.br

\section{Resumo}

O objetivo do presente trabalho é apresentar os elementos essenciais que caracterizam a pregação no período da Escolástica Barroca a partir dos sermões do Padre Antônio Vieira. A análise dos sermões permite aprofundar as premissas conceituais, epistemológicas, religiosas e sociais acerca do significado dos conteúdos do saber produzido pela Companhia de Jesus no âmbito da evangelização. Na articulação do modelo sacramental e do princípio da encarnação pode-se chegar a perceber os diferentes níveis do discurso de Vieira, que, por sua vez, implica a discussão de questões retóricas, sociais e políticas. $O$ princípio paradoxal do cristianismo, ou seja, a doutrina do Verbo encarnado revela-se, do ponto de vista metodológico, excelente guia de leitura para os sermões, bem como para a literatura de espiritualidade da Companhia de Jesus.

Palavras-chave: Sermões. Método de pregação. Evangelização. Princípio da encarnação. 


\section{Abstract}

The aim of this work is bring essentials elements that characterize Baroque Scholastic's preaching based on Father Antonio Vieira's sermons. The Preaching's analysis allows to go deep into conceptual, epistemological, religious and social premises about the meaning of knowledge contents produced by the Jesuitical Company on the area of evangelization. Articulating the sacramental model and the incarnation principle it is possible to notice the different levels of Vieira's speeches that imply discussions of rhetoric, socials and political questions. The christianism paradoxal principle, it means the doctrine of incarnate Word, reveals in a methodological point of view, excellent guide to read Vieira's Preaching, and the spirituality literature of the Jesuitical Company.

Keywords: Sermons. Preaching methodology. Evangelization. Incarnation principle.

\section{INTRODUÇÃO}

A pregação é um tema de fundamental importância para os membros da Companhia de Jesus. O sermão era considerado um meio privilegiado de transmissão cultural (MASSIMI, 2005). Os jesuítas não só consideram a pregação para o uso da transmissão e defesa da fé, mas como um verdadeiro laboratório para o exercício da arte retórica, fazendo despontar o poder da palavra. A tentativa de persuadir os ouvintes desponta como a finalidade principal do sermão. A tese de historiadores como Majorana (1996) e Châtellier (1995) - especializados na área da oratória sagrada medieval e moderna - considera que o significado da persuasão por parte dos pregadores não era a de simplesmente utilizar da técnica da oratória sagrada para domesticar as populações e teatralizar a prática oratória, como foi interpretado e sustentado por historiadores da cultura, mas se pretendia, com o uso da palavra, atingir os sentimentos, a inteligência e mover a vontade dos ouvintes. Dessa forma, vê-se que a ordem e coerência exigida na fala e nos gestos do pregador estavam determinados por um percurso próprio da gnoseologia aristotélico-tomista. Além disso, nota-se uma preocupação dos pregadores jesuítas 
de articular a palavra e a imagem. A teologia da palavra de Deus nos sermões de Vieira, por exemplo, está estreitamente ligada ao uso da imaginação sensorial como suporte para a meditação e explicitação das verdades da fé cristã. Para Inácio de Loyola a aplicação dos sentidos contribui, na perspectiva de uma espiritualidade da encarnação, a transformar a imaginação - situada na fronteira dos sentidos e do pensamento - em sentimentos dirigidos a Cristo (KOLVENBACH, 1999). E nesse caso, os sentidos e a contemplação das imagens antes de conspirar contra as verdades e mistérios da fé, apresentam-se como canais de acesso à contemplação.

Para Broggio (2004), o problema mais urgente para a hierarquia eclesiástica no período da chamada Contra-Reforma era a procura pela formação e instrução religiosa que poderia ser oferecida por meio da imprensa - difusão de livros, catecismos - da pregação itinerante da Palavra de Deus, das missões e do ensino. Esses meios eram considerados como que antídotos com relação ao desenvolvimento de grupos heterodoxos, e a Companhia de Jesus inseriu-se nessa grandiosa obra de aculturação religiosa nos diferentes campos: na direção espiritual, na pregação, na produção editorial, na formação das classes dirigentes, na pastoral de massas e nas missões fora da Europa.

A palavra ocupa um lugar central na auto-compreensão da Companhia de Jesus e no contexto da Contra-Reforma. Os sermões de Vieira nos apontam para a centralidade deste veículo de comunicação na transmissão da fé. De acordo com Massimi (2005, p. 260):

No Brasil da época colonial, onde a maioria da população é iletrada, o recurso à palavra oral como veículo transmissor de idéias e como meio terapêutico é prioritário. Além do mais, este recurso foi amplamente valorizado em sua conotação de cura, no âmbito da tradição cultural indígena, pois desde o século XVI, nos relatos e cartas dos viajantes e missionários, ressalta a função taumatúrgica atribuída à palavra pelos nativos. Por outro lado, na Idade Moderna o exercício da arte retórica constituiu-se como lugar de experimentação das potencialidades da palavra, sendo esse processo um pressuposto indispensável para o uso dela com função terapêutica [...].

Por outro lado, a valorização da palavra e da imagem, visando à transmissão dos conteúdos da fé, evidencia-se quando se examina com atenção a relação entre os sentidos humanos e a teoria das paixões, que para Vieira são 
reconhecidas como motores fundamentais do comportamento individual e social. Os dois sentidos principais mencionados por Vieira nos sermões são: o ouvido e o olhar. Segundo o pensamento de Aristóteles e de Tomás, esses dois sentidos nos permitem distinguir entre as coisas que se devem contemplar e aquelas coisas necessárias de se fazer (AQUINO, 1997, p. 50). Vieira os privilegia como possíveis canais de acesso à fé, de comunicação da verdade. Essas funções revestem-se de particular significado como a plataforma para a penetração no mundo espiritual. Os ouvidos "são a porta da alma" pois servem diretamente à atividade intelectiva, tendo como qualidade especifica conhecer os diferentes sons e vozes. Tal qualidade é fundamental quando se trata de distinguir a voz de Cristo da dos inimigos que soam à porta da alma. A maior enfermidade é ter ouvidos para não ouvir. Contudo, o pregador não pode contentar-se que sua voz chegue aos ouvidos dos ouvintes, um sermão só pode mover se o pregador pregar também aos olhos. Como se faz para pregar aos olhos? Os efeitos do sermão se obscurecem se das palavras não se seguir imediatamente as obras, e se a vida do pregador não for uma apologia do que ensina, e isso é pregar aos olhos.

Será de suma importância, então, deter-se na figura do pregador e apresentar a hipótese de leitura dos sermões segundo uma análise que leva em conta os conteúdos reais do saber próprio da Companhia de Jesus.

\section{Antônio Vieira: dissimili similitudini}

Tantas são as biografias que se escreveram sobre o padre Antônio Vieira. A sua figura escapa a um único flash. Quando se faz qualquer análise, seja de um objeto, de uma dada realidade ou de um sujeito, devemos sempre considerá-los dentro da categoria de complexidade. As biografias tendem a reduzir e mostrar não a figura complexa mas a controversa. Segundo Pécora (1994, p. 61), já é um lugar comum aos críticos de Vieira acentuar suas contradições e incoerências, sendo raros os autores que procuram mostrar a unidade de sua obra e pensamento. O seu primeiro biógrafo, por exemplo, o jesuíta Pe. André de Barros (1745) descreve o Vieira zeloso e santo, jesuíta modelo; em contrário temos o bispo de Viseu Francisco Lobo (1897), que apresenta o nosso autor como homem ambicioso e vaidoso. Os estudiosos se dividem e apontam para a diversidade da atividade apostólica de Vieira. 
Hernani Cidade (1955), por exemplo, prefere salientar a atividade política e diplomática; Palacín (1998) apresenta as contradições e fragmentações na apresentação da vida de Vieira; Cantel (1959) faz o estudo de estilo do sermonário e a apresentação como teólogo; já Luis Gonzaga Cabral (1901) mostra o incansável pregador. Como vemos, vão surgindo uma variedade de imagens: desde o político maquiavélico (AZEVEDO, 1931) que pretende a todo o custo fortalecer o Estado português, até a imagem do "apóstolo do Brasil" (LEITE, 1950), do Pai Grande dos Índios (BESSELAAR, 1981), do abolicionista (LINS, 1956), do "Judas do Brasil" (LISBOA, 1952), do Vieira judaizante e sebastianista (SARAIVA, 1980).

Os anacronismos em relação à sua obra e as concepções estereotipadas de sua vida devem-se principalmente ao imenso aparato crítico que sua personalidade suscitou. Contudo, o que predomina é uma visão dispersiva e fragmentária. Basta pensar, por exemplo, na tentativa de diversos autores de se concentrar na capacidade estilística de sua oratória, exaltando de tal forma, como se Vieira tivesse apenas a intenção de um cultivo da língua portuguesa por ela mesma, tal como foi realizado por autores oitocentistas ${ }^{1}$ no julgamento de sua produção.

Nesse sentido, ao analisar-se a situação de produção dos sermões nota-se que ela reflete esse homem do século XVII, português, missionário jesuíta, contrarreformista, neoescolástico, enfim, sua obra é espelho de sua personalidade. A variedade espanta. Os sermões foram produzidos em tempo e espaço diversos. Alguns podem ser identificados em termos de 60 anos de diferença, e na distância espacial da América e Europa, desde as aldeias e florestas brasileiras às luxuosas cortes e igrejas europeias. A mudança de circunstâncias e o auditório ao qual se dirige são outros fatores imprescindíveis e determinantes no mosaico da produção de Vieira. Há sermões dirigidos aos membros da Corte Real; aos militares portugueses e espanhóis empenhados na missão de combate às forças hostis; sermões em italiano, com a presença de cardeais no palácio de Cristina da Suécia, bem como para a comunidade portuguesa em Roma; sermões no Colégio dos jesuítas de Salvador e aos noviços da Companhia em Roma; às religiosas de Odivelas e aos acadêmicos de

1 Autores como Antonio Feliciano de Castilho e Camilo Castelo Branco, ambos, tendem a separar em Vieira a sua forma estilística do seu conteúdo, e se esquecem de um dado imprescindível em âmbito contextual, tal como o Barroco Luso-Brasileiro.

Rev. Pistis Prax., Teol. Pastor., Curitiba, v. 2, n. 1, p. 211-230, jan./jun. 2010 
Coimbra; aos pretos e seus senhores num engenho na Bahia, e tantos outros. Essa é uma pequena amostra de quanto uma descrição dessas circunstâncias nos aproximam da mobilidade do homem Antônio Vieira e, no fundo, são instrumentos para decifrar os sentidos de determinados discursos e sermões.

Os temas, por conseguinte, são múltiplos: valor dos sacramentos, missão dos portugueses no mundo, responsabilidade frente às guerras, o testemunho dos santos e a vida mística, legitimação do poder do rei português, dos critérios de justiça e da arrecadação de impostos, do desejo humano, da manifestação encoberta da divindade, do cativeiro indígena, da corrupção geral das gentes e do governo, da desgraça econômica das minas de ouro; do destino universal dos portugueses, e a implantação do Império de Cristo na Terra.

A consequência imediata, do ponto de vista metodológico, é adotar uma posição hermenêutica que respeite a unidade teológico-retórica e política do seu pensamento. Nesse sentido compartilhamos a tese de Pécora (1994, p. 66-67), segundo a qual Vieira aparece como um homem visionário, extremamente ligado à profecia:

[...] mas ele nunca o foi fora de um forte senso político, e, mais do que isso, jurídico-institucional; também nunca o foi fora de uma referência básica às concepções da teologia ortodoxa, notadamente tomista e neotomista; principalmente, nunca o foi como uma espécie de gênio em combustão consigo próprio, fora de contexto e história. Desse ponto de vista, se é o caso de buscar uma hipótese de unidade - e está claro que eu penso que sim -, teria que haver mais cuidado no sentido de que ela se fizesse, primeiro, mediante a consideração efetiva dos vários pontos constantes em sua organização discursiva, segundo, mediante a consideração da pertinência histórica dessa organização.

Essa premissa metodológica é fundamental para a leitura dos sermões, e com ela pretendemos nos confrontar na apresentação deste artigo. Isso significa incorporar um modo de análise no qual transpareçam as dimensões políticas, proféticas, teológicas e doutrinais em movimento dialético e não contrastantes entre si. Além disso, compartilhamos a perspectiva de autores como Massimi (2001, 2003), Carvalho da Silva (2000) e Martins de Assis (2001), que têm conduzido suas pesquisas em torno dos sermões de Vieira, colocando-se numa posição em que a interpretação possa se sustentar no que advém do interior de sua obra. 
À luz dessas constatações, a hipótese de uma leitura dos sermões em chave teológico-fundamental poderia nos conduzir a uma tese senão diferente, pelo menos correspondente àquela visão unitária enfatizada por Pécora (1994). Em consequência, o princípio teológico de unidade seria a Encarnação. Assim, a afirmação paradoxal "o Verbo de Deus se fez carne" constitui, para Vieira, o centro e o ponto de encontro insubstituível e definitivo entre o evento eterno e o temporal, entre o absoluto e o contingente, entre o divino e o humano. Esse princípio paradoxal do cristianismo revela-se, do ponto de vista metodológico, excelente guia de leitura para os sermões e para a literatura de espiritualidade da Companhia de Jesus. Em Vieira, por exemplo, o mistério da Encarnação vem contemplado, sobretudo, como momento da descida do Verbo de Deus e como ascensão do ser humano ao lugar da divindade. Essa perspectiva descendente, do alto até o baixo, tem como finalidade indicar o movimento misericordioso de Deus na obra de redenção da humanidade para poder elevá-la. A ascensão da humanidade funda-se na descida de Deus. De outro lado, a encarnação não é vista simplesmente como uma descida de solidariedade para com a humanidade, mas como um verdadeiro processo de humilhação e obediência de Cristo ao Pai. Essa chave de leitura dos sermões de Vieira, certamente, aplica-se também à autocompreensão da Companhia de Jesus e da prática da pregação evangélica.

\section{ARS Predicantis em Vieira}

No célebre Sermão da Sexagésima, Vieira expõe seu modo de compreender a arte de pregar, e nele descreve o que é e qual o modo de proceder de um verdadeiro orador sacro. Para Vieira, a função do pregador é semear a palavra de Deus de tal modo que possa persuadir o ouvinte de que, com seu entendimento, perceberá a luz da graça divina. De acordo com Mendes (1989), não se pode entender a obra de Vieira sem considerar dialeticamente o ethos do pregador, do qual derivam tanto o pathos, domínio emocional, quanto o logos, que seria o componente simbólico e verbal. O modo de pregar vieiriano segue, portanto, a tríade indicada na Retórica de Aristóteles. No entanto, para Vieira não bastavam o domínio e a confiança nas técnicas retóricas. O pregador sacro não é somente um orador, é também um apóstolo, é ainda um profeta. O modelo de oratória sacra proposto pelo autor compreende-se em uma unidade indissolúvel entre teologia, retórica e política. Segundo diz Pécora (2000, p. 25): 
Ao pregador digno do nome cabe necessariamente examinar os signos divinos nas coisas, ordená-los como provas discursivas capazes de mover vontade e razão dos fiéis e, enfim, sistematizá-los como política voltada para o triunfo histórico do corpo místico.

Para Hansen (1994, p. 33), o estilo de Vieira tem desenho e cor e, de modo geral, é uma severa crítica ao estilo conceitualista de pregar:

Como articulação icástica da verdade teológica, o desenho é proporcionado ao fim do sermão sacro, pois esse é gênero popular que deve, antes de tudo, ensinar e mover, docere et movere. Segundo o juízo de Vieira, a cor não é catártica quando é aplicada sem proporção: é inverossímil, pois desvia o entendimento para as manifestações sensíveis e confusas do gosto momentâneo, que especifica tipos vulgares ou néscios. O que deve significar que de modo algum Vieira é contrário à cor, mas contra determinados graus e circunstancias da sua aplicação que a tornam indiscreta ou indecorosa.

Antônio Vieira, no Sermão da Sexagésima, pregado em 1655 na Capela do Palácio Real de Lisboa, faz uma verdadeira teologia da pregação. Nele se encontram os princípios que o autor referiu para que se pudesse proceder à leitura de todos os demais sermões por ele produzido. Nesse sermão, comentando a parábola do semeador, Vieira extrai os elementos essenciais presentes na pregação evangélica e descreve os três componentes que entram em jogo na semeadura da palavra divina: em primeiro lugar o pregador, em seguida Deus e, por fim, os ouvintes. Um sermão, visando à conversão, há de haver três concursos: o pregador com a doutrina persuadindo, a graça de Deus iluminando, e o ouvinte, que com o seu entendimento passa a perceber os sinais da graça divina. A conversão é uma nova visão proporcionada pela intrínseca relação entre doutrina, graça e conhecimento:

Para um homem se ver a si mesmo são necessárias três coisas: olhos, espelho e luz. Se tem espelho e é cego, não se pode ver por falta de olhos; se tem espelho e olhos, e é de noite, não se pode ver por falta de luz. Logo há mister luz, há mister espelho e há mister olhos. Que coisa é a conversão de uma alma senão entrar um homem dentro em si, e ver-se a si mesmo? Para esta vista são necessários olhos, é necessária luz, e é necessário espelho. O pregador concorre com o espelho, que é a doutrina; 
Deus concorre com a luz, que é a graça; o homem concorre com os olhos, que é o conhecimento (VIEIRA, 1998, tomo I, p. 33).

Vieira estrutura o sermão em torno de uma pergunta: qual é a razão, uma vez considerados esses componentes, da palavra de Deus não produzir os frutos que são necessários na vida dos ouvintes? De quem será a culpa? E, em primeiro lugar, se pergunta: será culpa de Deus, que não dá sua graça? A sua resposta segue a doutrina do Concílio de Trento:

Primeiramente por parte de Deus não falta, nem pode faltar. Esta proposição é de Fé, definida no Concilio Tridentino, e no nosso Evangelho a temos. Do trigo que deitou à terra o semeador, uma parte se logrou e três se perderam. E porque se perderam estas três? A primeira perdeu-se, porque a afogaram os espinhos; a segunda, porque a secaram as pedras; a terceira, porque a pisaram os homens, e a comeram as aves. Isto é o que diz Cristo; mas notai o que não diz. Não diz que parte alguma daquele trigo, se perdesse por causa do Sol ou da chuva. A causa por que ordinariamente se perdem as sementeiras, é pela desigualdade e pela intemperança dos tempos, ou porque falta ou sobeja a chuva, ou porque falta ou sobeja o Sol (VIEIRA, 1998, tomo I, p. 34).

O fracasso do sermão, portanto, não pode estar ligado à falta da graça. Então, Vieira acena para as seguintes alternativas: ou é por falta de eficácia dos ouvintes ou dos pregadores. Aos ouvintes, segundo Vieira, não pode ser atribuída a culpa, pois a força da palavra divina é tanta que produz efeitos nos seres humanos tanto nos corações embaraçados como espinhos e em corações secos e duros como as pedras:

Os ouvintes, ou são maus ou são bons: se são bons, faz neles fruto a palavra de Deus; se são maus, ainda que não faça neles fruto, faz efeito. No Evangelho o temos. O trigo que caiu entre os espinhos, nasceu, mas afogaram-no: Simul exortae spinae suffocaverunt illud. O trigo que caiu nas pedras, nasceu também; mas secou-se: Et natum aruit (VIEIRA, 1998, tomo I, p. 34).

Uma vez excluídos a graça divina e o sujeito ouvinte da Palavra, admite-se que a falta apenas pode ser do pregador, embora não seja atribuída a ele a causa principal do fracasso do sermão. Ela se deve, sobretudo, ao falso 
testemunho do pregador. O testemunho se dá na ação, e por meio dessa se pode conhecer a essência do pregador:

A definição do Pregador é a vida e o exemplo. Por isso Cristo no Evangelho não o comparou ao semeador, senão ao que semeia. [...] uma coisa é o semeador e outra o que semeia; uma coisa é o Pregador e outra o que prega. O semeador e o Pregador é nome; o que semeia e o que prega é ação; e as ações são as que dão o ser ao Pregador. Ter o nome de Pregador, ou ser pregador de nome não importa nada; as ações, a vida, o exemplo, as obras, são as que convertem o mundo" (VIEIRA, 1998, tomo I, p. 36).

Assim, para Vieira, o objeto da pregação está intimamente relacionado à experiência cristã do pregador. Os recursos retóricos não têm força por si mesmos comparados com a capacidade de persuasão que tem o testemunho de vida. O melhor conceito que o pregador leva ao púlpito 'é o que de sua vida tem os ouvintes'. Isso não significa que Vieira recuse totalmente o ornato dialético ou o conceito engenhoso ${ }^{2}$, como procedimentos artísticos inadequados em si, mas sugere que o risco está em causar uma ruptura que leve a separar a retórica do projeto teológico salvífico. O pregador deve saber compor dialeticamente os recursos da técnica discursiva com sua capacidade de ler os sinais divinos presentes no mundo.

É exatamente isso que Vieira critica no sermão da Sexagésima quando repreende duramente os dominicanos do Paço, os quais não tratavam de

2 O termo está intimamente relacionado à sensibilidade do barroco. O seu sentido encontramos em obras que versarão sobre estudos estilísticos, como é possível ver claro em Gracián, para o qual "son los conceptos hijos más del esfuerço de la mente que del artifício; concibense acaso; salen a luz sin magistério. [...] No se puede negar Arte donde amenaçan yerros, ni hábito donde reina la dificultad: ármase con reglas um Sylogismo, fórjese con ellas un Concepto. Mendiga dirección todo artifício, quánto más sutilezas del Ingenio! Nace el hombre tan desnudo en alma, como en el cuerpo, de noticias, y de plumas; pero la industria le desquita com ventajas" (GRACIÁN, 1998, p. 135). O conceito engenhoso, portanto, é uma criação artificial da mente, segundo regras precisas, de modo a poder produzir simpatia e atingir com impacto o interlocutor. Gracián diz que um entendimento sem Conceito é como o Sol sem os seus raios, a agudeza é o alimento da alma. Outros jesuítas, como o Tesauro em seu Cannochiale aristotelico, e Sforza Pallavicino, no Trattato dello stile e del dialogo, produziram esses importantes textos que são uma teorização literária do barroco, nos quais se enaltece o uso dos conceitos e a sua capacidade de ensinar e impressionar os ouvintes causando surpresa e maravilha (RAIMONDI, 1960).

Rev. Pistis Prax., Teol. Pastor., Curitiba, v. 2, n. 1, p. 211-230, jan./jun. 2010 
'descobrir' a dinâmica transcendente desses sinais, mas se contentavam em reduzir o mistério na aplicação das regras cultas em uso. Esse tipo de procedimento faz o pregador girar em torno dos ornamentos e, desse modo, esquecer do núcleo essencial que deve ser transmitido ${ }^{3}$. O sermão, nessa visão, não é lugar para mostrar a alta capacidade do pregador: sua eloquência, o uso gramatical, o virtuosismo e o entusiasmo do sujeito que está no púlpito. Ao contrário, é preciso respeitar a natureza e o objetivo para o qual se exerce esse ministério, isto é, conduzir e afetar uma alma para que se converta. Para Vieira, a conveniência do público para com o pregador foge desse objetivo:

Para que os pregadores saibam como hão de pregar e os ouvintes a quem hão de ouvir, acabo com um exemplo do nosso reino e quase dos nossos tempos. Pregavam em Coimbra dois famosos pregadores ambos bem conhecidos por seus escritos; não os nomeio porque os hei de desigualar. Altercou-se entre alguns doutores da Universidade, qual dos dois fosse maior pregador. E como não há juízo sem inclinação, uns diziam este; outros aquele. Mas um lente, que entre os mais tinha maior autoridade, concluiu d'esta maneira: entre os dois sujeitos tão grandes não me atrevo a interpor juízo, só direi uma diferença que sempre experimento. Quando ouço um, saio do sermão muito contente do pregador; quando ouço outro, saio muito descontente de mim. Semeadores do Evangelho, eis aqui o que devemos pretender nos nossos sermões, não que os homens saiam contentes de nós, senão que saiam muito descontentes de si; não que lhes pareçam bem os nossos conceitos, mas que lhes pareçam mal os seus costumes, as suas vidas, os seus passatempos, as suas ambições e enfim todos os seus pecados. Contanto que se descontentem de si, descontentem-se embora de nós, dizia o maior de todos os pregadores, S. Paulo: Se eu contentara aos homens não seria servo de Deus. Oh! contentemos a Deus, e acabemos de não fazer caso aos homens! (VIEIRA, 1998, tomo I, p. 51-52).

Os ouvintes não se convertem, segundo Vieira, porque os pregadores pregam só aos ouvidos. Um sermão só pode mover se o pregador pregar também aos olhos, e isso o faz quando dá o testemunho de sua vida. Se a vida do pregador for uma apologia contra a doutrina que prega, se das palavras não se

3 No Sermão de Xavier acordado, Vieira dá o seguinte juízo: “São alguns pregadores como sacristãos da aldeia, que no dia do orago cobrem o altar e o retábulo de tantos ramalhetes, que não se vê o santo" (VIEIRA, 1998, v. IX, p. 139).

Rev. Pistis Prax., Teol. Pastor., Curitiba, v. 2, n. 1, p. 211-230, jan./jun. 2010 
seguirem as obras, então, o abalo e os efeitos do sermão serão escurecidos. Nesse sentido, o que Vieira pede, em perspectiva testemunhal, não é nenhuma coisa extraordinária, mas a simples diligência do pregador, depois de achar no evangelho o herói ou sujeito que utilizará no sermão, de voltar a buscar em sua própria existência esse personagem. Vieira diz que sempre agiu dessa maneira quando ele pessoalmente pregava (VIEIRA, 1998, v. IX, p. 28). Ou seja, os sermões entram na mesma dinâmica dos Exercícios Espirituais, pois são ocasiões para que o pregador possa examinar-se e discernir o ritmo vital da alma e do corpo, da vontade e da inteligência, da imaginação e do coração ${ }^{4}$. De qualquer forma, "o admirável”, segundo Vieira, em matéria de pregação é o grande e universal fruto que fez a do profeta Jonas em Nínive. E por que tão extraordinária, sendo o sermão brevíssimo em uma cidade envolvida em maldades e um povo sem fé? Porque Jonas foi um "pregador vomitado pelas ondas" 5 , isto é, pregava nele toda a experiência de suportar as dificuldades, os perigos, as tempestades e o assombro diante da morte.

Quanto ao estilo a ser usado nas pregações, principalmente com relação às palavras, Vieira sugere a metáfora das estrelas do céu. Pois o mais antigo pregador foi o céu, segundo a expressão escriturística: "Coeli enarrant gloriam Dei, et opera manuum ejus annuntiat firmamentum" (S1. 18,1). As estrelas, segundo o jesuíta, são palavras do céu, sendo muito distintas, muito claras, e altíssimas. Essas três características não estão em oposição. Por isso, o estilo pode ser claro para que entendam os que não sabem, e alto para que tenham muito que escavar e entender os que são sábios. Assim como o

4 A arte sermonária de Vieira está conectada em linha direta com o uso dos sentidos proveniente do método de Santo Inácio. É o que afirma Saraiva: “Contentemo-nos em lembrar que, num gênero como o sermão, que procura despertar a imaginação dos ouvintes, as imagens desempenham um papel muito importante; que os textos sagrados punham à disposição dos pregadores um arsenal inesgotável de figuras, parábolas, metáforas; e, finalmente, que o recurso à imaginação sensorial como suporte da meditação era um método recomendado por Santo Inácio e exemplificado nos Exercícios Espirituais. O nosso ponto de vista dispensanos de comentar o "Quereis ver? Olhai“" ou as outras formas de apelo à visão que encontramos muitas vezes no nosso Jesuíta” ( SARAIVA, 1980, p. 381).

5 Vieira, 1998, v. III, p. 450. Importante ressaltar a circunstância desta pregação de Vieira: prega no arquipélago de São Miguel, nos Açores, no Colégio da Companhia de Jesus, depois de ter escapado de um naufrágio. Desse modo Vieira compara-se a São Paulo, lançado pelas ondas na Ilha de Malta, e ao profeta Jonas, vomitado pela baleia nas praias de Nínive. Esse seria um exemplo do que é buscar na própria experiência a matéria para o sermão.

Rev. Pistis Prax., Teol. Pastor., Curitiba, v. 2, n. 1, p. 211-230, jan./jun. 2010 
agricultor acha nas estrelas uma orientação para o seu trabalho e o matemático nelas vê possibilidades para seus juízos e observações, do mesmo modo o pregador-exegeta encontrará nelas uma forma de orientar-se na pregação. Se o púlpito é o poço de Sicar (VIEIRA, 1998, vol. III, p. 450), onde se bebem as águas saudáveis da verdade; ou o teatro (VIEIRA, 1998, tomo I, p. 50), onde se representam os dramas; ou ainda o pináculo do templo (VIEIRA, 1998, tomo I, p. 47), pois é o lugar mais alto, o estilo de pregar não pode ser escuro, mas revelativo.

Outra circunstância à qual o pregador deve estar atento é quanto à matéria da pregação. $\mathrm{O}$ assunto deve ser um só. Vieira compara o sermão com a árvore, que possui um único tronco, do qual saem uma variedade de ramos:

Uma árvore tem raízes, tem tronco, tem ramos, tem folhas, tem varas, tem flores, tem frutos. Assim há de ser o sermão: há de ter raízes fortes e sólidas, porque há de ser fundado no Evangelho; há de ter um tronco, porque há de ter um só assunto e tratar uma só matéria; deste tronco hão de nascer diversos ramos, que são diversos discursos, mas nascidos da mesma matéria, e continuados nela; estes ramos não hão de ser secos, senão cobertos de folhas, porque os discursos hão de ser vestidos e ornados de palavras (VIEIRA, 1998, tomo I, p. 42).

Entretanto, quanto mais vai ficando clara a maneira que Vieira tem de impostar a pregação sacra, tanto mais o vai, também, a ideia de que ela não é um exercício de memorialística, ou ainda, de simples repetição do que outros disseram sobre a matéria. $\mathrm{O}$ modo de proceder do pregador comporta um trabalho de inteligência pessoal. O jesuíta afirma que o que vai dizer o pregador não deve só sair da sua boca, pois o que sai só da boca para nos ouvidos; e o que nasce do juízo penetra e convence o entendimento (VIEIRA, 1998, tomo I, p. 44). Daí que, para Vieira, entra um segundo componente na pregação, que é a voz. Ele se pergunta: deverá o pregador bradar como um trovão, ou serem suas palavras suaves como aparece na oração de Moisés: "Concrescat ut pluvia doctrina mea: fluat ut ros eloquium meum"? (Dt. 32,2). E continua: a definição do pregador é voz que arrazoa ou voz que brada? (VIEIRA, 1998, tomo I, p. 45).

Mas o que se pode extrair de positivo é que, consideradas todas essas circunstâncias, nenhuma delas pode ser a causa efetiva dos poucos frutos que a palavra de Deus causa na vida dos ouvintes. Nem a circunstância da pessoa do pregador, nem a do estilo utilizado, nem a da matéria escolhida, nem a da 
ciência do pregador, e tanto menos a sua voz constitui empecilho principal. Entretanto, isso não quer dizer que secundariamente não exerçam sua influência. Prova disso é que no Sermão da Sexagésima Vieira cuida de mostrar que em todas elas existem faltas graves. Contudo, a razão principal deve-se ao "falso testemunho" do pregador que, não se refazendo aos textos das Sagradas Escrituras e não tomando o texto em seu sentido original, distorce, seguindo seus interesses e o propósito de agradar ao auditório:

É porque as palavras dos pregadores são palavras, mas não são palavras de Deus. [...] Se os pregadores semeiam vento, se o que se prega é vaidade, se não se prega a palavra de Deus, como não há a Igreja de Deus do colher tormenta, em vez de colher fruto? Mas dir-me-eis: Padre, os pregadores de hoje não pregam o Evangelho, não pregam as sagradas Escrituras? Pois como não pregam a palavra de Deus? Esse é o mal. Pregam palavras de Deus, mas não pregam a palavra de Deus: Qui habet sermonem meum, loquatur sermonem meum vere (Jr, 23,28), disse Deus por Jeremias. As palavras de Deus pregadas no sentido em que Deus as disse, são palavras de Deus; mas pregadas no sentido que nós queremos, não são palavras de Deus, antes podem ser palavras do Demônio. [...] O Diabo tentou a Cristo no deserto, tentou-o no monte, tentou-o no templo: no deserto tentou-o com a gula, no monte tentou-o com a ambição, no templo tentou-o com as Escrituras mal interpretadas, e essa é a tentação de que mais padece hoje a Igreja, e que em muitas partes tem derrubado dela, senão a Cristo, a sua fé (VIEIRA, 1998, tomo I, p. 46).

Para produzir o efeito desejado o pregador, tal como o médico com seu paciente, não deve reparar no gosto do ouvinte: "Que médico há que repare no gosto do enfermo, quando trata de lhe dar saúde? Sarem, e não gostem; salvem-se, e amargue-lhes, que para isso somos médicos de almas" (VIEIRA, 1998, p. 47).

Vieira compara o pregador a um médico de almas 6 . Ele cuida das feridas através do discurso, sua palavra tem uma força mágica e curativa. Tal concepção, segundo diz Mendes (1989, p. 168), não é algo original de Vieira,

6 Segundo Carvalho da Silva (2000, p. 23-42) essa ideia em Vieira tem suas origens em Platão e nos estoicos, em conceitos derivados da medicina galênica e relacionados à ética aristotélicotomista, e muito utilizado pelos membros da Companhia de Jesus. A medicina da alma parece ser a ciência de Vieira, que visa à conversão, e implica o esforço e trabalho paciencioso do exame de si mesmo.

Rev. Pistis Prax., Teol. Pastor., Curitiba, v. 2, n. 1, p. 211-230, jan./jun. 2010 
pois a concepção do discurso como energei $a^{7}$, que atua, vence e corta os males, está presente em vários outros pregadores. Contudo, para o caso do nosso jesuíta, semear a palavra de Deus, através da pregação evangélica, faz parte de uma luta contra as forças que nos querem causar o mal e nos fazer perder; por isso, o médico de almas tem de aplicar a terapia adequada, ensinando, convencendo, deleitando e movendo o ouvinte.

Feitas todas essas considerações sobre a compreensão da arte de pregar em Vieira, resta-nos mostrar como nesse sermão-programa está presente a hipótese que norteia nosso trabalho: que é o principio da Encarnação como fundamento para compreender a teologia da pregação em Vieira. $\mathrm{O}$ autor parte de uma analogia: se o pregador evangélico tem a missão de converter pela pregação, com palavras e obras, é por que, em primeiro lugar, a sua é participação na missão do Filho de Deus mandado ao mundo para a obra da conversão:

Quis Deus converter o mundo, e que fez? Mandou ao mundo seu Filho feito homem. Notai. O Filho de Deus enquanto Deus, é palavra de Deus, não é obra de Deus: Genitum, non factum. O Filho de Deus enquanto Deus e Homem, é palavra de Deus e obra de Deus juntamente: Verbum caro factum est. De maneira que até de sua palavra desacompanhada de obras, não fiou Deus a conversão dos homens. Na união da Palavra de Deus com a maior obra de Deus consistiu a eficácia da salvação do mundo (VIEIRA, 1998, tomo I, p. 37).

No Sermão do Nascimento do Menino Deus, Vieira é mais claro a esse respeito. Trata-se de um discurso póstumo publicado e classificado pelo padre André de Barros que é de uma atualidade impressionante, isto é, vemos

7 A esse respeito, Florenskij, falando da palavra como energia humana, que se manifesta por meio da pessoa, sugere o peso mágico que aquela exerce: "Con la parola che io pronuncio si mette in moto la mia verità concentrata, la forza della mia attenzione accumulata, e si sospinge avanti nello spazio. Se incontro um oggetto in grado di ricevere un impulso della volontà, allora la parola vi provoca quel cambiamento che quest'oggetto è capace di sperimentare, e penetra nell'oggetto con tutte le spire della volontà che è stata ridestata in colui che ha pronunciato la parola attraverso le spire del seme. Se l'oggetto della nostra parola è un uomo, o un altro essere dotato di ragione o per lo meno di coscienza, allora questa parola entra, insieme ad altri effetti, e produce, in virtù di un'ingente spinta di volontà dell'intero popolo, una pressione che obbliga a sperimentare, a vivere gli strati sovrapposti del sêmen, a percepirli e a riflettervi, di modo che tutta la sua attenzione ne risulti indirizzata in quella direzione e venga provocata la corrispondente espressione della volontà" (FLORENSKIJ, 2001, p. 65).

Rev. Pistis Prax., Teol. Pastor., Curitiba, v. 2, n. 1, p. 211-230, jan./jun. 2010 
a exposição de uma teologia que nasce da experiência da Revelação de Deus. O sermão todo é pensado em torno do paradoxo de Moisés mudo, que impedido de pronunciar a sua voz por causa de uma dificuldade na língua, é substituído por seu irmão a fim de realizar a missão de libertar o povo de Israel. De outra parte, Vieira coloca o Messias vindo ao mundo, que pela sua encarnação, em Belém, mostra-se um menino, também mudo, mas que prega. A proposta do sermão é ouvir o pregador que é o Cristo nascido. O problema todo é como fala e prega esse infante? Por isso propõe uma belíssima distinção entre a voz humana e a divina:

Entre a voz humana e a divina - diz ele - há esta diferença: que a voz humana percebe-se com o ouvido, a voz divina com a vista: Humana vox auditu, divina visu percipitur. E porque a filosofia desta resposta parece dificultosa de entender, o mesmo Filo pede a razão, e a dá: Quare? Quia quaecumque Deus dicit, non verba sunt, sed opera, quorum judicium non tantum est penes aures, quam penes oculos. Excelentemente dito, e evidente. A razão de as vozes de Deus se perceberem com os olhos, e não com os ouvidos, é porque as vozes de Deus não são palavras, são obras; e o juízo das obras não pertence ao ouvido, senão à vista: as palavras ouvem-se, as obras vêem-se (VIEIRA, 1998, tomo I, p. 126).

Esse trecho nos oferece a oportunidade de ver a articulação que Vieira faz entre a Criação, Redenção e Revelação. A obra de Deus por excelência é a criação. A nova criação, aquela que se vê no rosto do Deus-Encarnado, é a obra da Redenção. Não por palavras Deus se revela, mas, sobretudo, pelas obras realizadas e que se vêem. Não há distinção entre o ouvir e o ver. Para Vieira, como já observamos outras vezes, o ouvir é ver, e daqui nasce a possibilidade de articular a Revelação de Deus com a Criação e a Redenção. Quando Deus diz já faz, conforme o Salmo 32,9: "Ele disse e foram feitas as coisas". Seguindo os ensinamentos de Demóstenes, sumo orador da Grécia, que perguntado qual era a primeira parte do perfeito orador, respondeu: Actio; e perguntado qual era a segunda, tornou a responder: Actio; e perguntado qual a terceira, respondeu do mesmo modo: Actio; Vieira destaca que a perfeição do orador não está nas palavras que se ouvem, mas nas ações que se vêem, e ainda, salienta a identidade entre a palavra feita carne e a palavra que estava eternamente com Deus. É a única e mesma Palavra: Deus como Pai e Deus que se faz carne. A palavra feita carne é a que revela a Palavra eterna.

Rev. Pistis Prax., Teol. Pastor., Curitiba, v. 2, n. 1, p. 211-230, jan./jun. 2010 
Considera a Santíssima Trindade como o perfeito orador, e cada uma das pessoas divinas como tendo uma específica função em sua relação amorosa. Se a finalidade do orador é ensinar, deleitar e mover, então ao Pai está o mover, ao Filho o ensinar e ao Espírito Santo o deleitar. Mas o Verbo de Deus quando se veste da natureza humana une essas três dinâmicas em si, de modo que o seu agir é ensinar tudo o que viu do Pai na novidade do Espírito Santo. Essa perspectiva trinitária tem sua expressão na encarnação. No presépio, o Menino Deus nascido, o desejado das gentes, moverá céu, terra e mar e todas as gentes de todas as nações. Esse é o fim da sua vinda, da sua encarnação. E Vieira, repreendendo a lição de São Bernardo, diz que a eficácia está em que o divino orador não quis falar aos ouvidos, senão à vista, através da ação:

E se perguntarmos ou inquirirmos causa de tão universal moção, consta que não foi outra, senão a que tiveram os pastores de Belém: $E t$ videamus hoc Verbum, quod factum est. - Isto é, verem o Verbo feito. Não digo feito homem, mas feito, como argutissimamente ponderou S. Bernardo: Ante non se movebant homines, dum Verbum erat tantum apud Deum: Antigamente, enquanto o Verbo somente era: In principio erat Verbum (Jo, 1,1) - não se moviam os homens. - At ubi Verbum, quod erat, factum est: mas, tanto que o Verbo, que somente era, foi feito: Tunc venerunt festinantes, tunc concurrerunt: então se moveram, então vieram e concorreram. - Tanta foi a eficácia que teve no Verbo divino o fazer-se: o não ser palavra dita, posto que dita por Deus, mas o ser palavra feita: Verbum, quod factum est. (VIEIRA, 1998, tomo I, p. 134).

Na conclusão do sermão Vieira faz um apelo à imitação. Ele diz que devemos observar o gesto da Estrela de Belém, que conduziu os pastores até Cristo no presépio e ali parou e ficou. A estrela ali ficou e se desfez, assim também deve fazer cada homem diante do Mistério da Encarnação. Vieira indica, portanto, que a contemplação de Cristo comporta, a kenosi, isto é, desfazer-se diante dele para agir como Ele:

Foi a Belém, chegou ao presépio, e ali parou, nem passou dali. Viu o Verbo quod factum est, e ninguém sabe o que foi feito dela, porque ali se desfez. Quem se não desfaz à vista do Verbo feito, não faz o que deve. Os olhos desfeitos em lágrimas, as respirações desfeitas em suspiros, $\mathrm{o}$ coração em amor (VIEIRA, 1998, tomo I, p. 137). 


\section{CONCLUSÃO}

Nesse ponto, podemos concluir afirmando que se Vieira ordena o sermão segundo o modelo sacramental, que "supõe a projeção permanente de Deus nas formas de existência do universo criado" (PÉCORA, 2000, p. 11), por outro lado é preciso dizer que o faz dentro de um princípio orientador que é aquele da Encarnação. No caso do orador sacro, as consequências são que esse deve procurar imitar a forma de ação do Cristo - o Filho enviado do Pai, que sendo rico se fez pobre, esvaziando-se a si mesmo e tomando a condição de servo.

Tentamos trazer à tona a complexa tradição de pertença do padre Antônio Vieira e, no conjunto de fatores, devemos sublinhar que ele assume, no seu trabalho teológico, a categoria do drama. O púlpito é transformado em palco onde o pregador deverá representar e atualizar o Revelar-se de Deus na história (HANSEN, 2008). A pregação, por sua vez, deve ajudar o ouvinte a rastrear no tumulto das coisas e do seu cotidiano o significado da história. Esse modo de pensar e proceder, de uma parte, é apto para integrar o vasto mundo das ciências, das artes, da literatura e das novas descobertas. Por outro verso, considerando que a linguagem da Revelação é estruturalmente antropológica, pois a Palavra de Deus tem como destinatário o ser humano, abrem-se perspectivas de diálogo e de defesa do ser humano, que, como assinalamos, é apenas consequência de uma radicalização do seguimento de Cristo feito Senhor para nós na cruz.

\section{REFERÊNCIAS}

AQUINO, T. La conoscenza sensibile: commenti ai libri di Aristotele de sensu et sensato, de memoria et reminiscentia. Bologna: Edizione Studio Dominicano, 1997.

AZEVEDO, J. L. História de Antônio Vieira. 2. ed. Lisboa: Clássica, 1931.

BARROS, A. Vida do apostólico Padre Antônio Vieira: chamado por antonomásia o Grande. Lisboa: Nova Officina Syviana, 1745.

BESSELAAR, J. V. D. António Vieira: o homem, a obra, as idéias. Lisboa: Instituto de Cultura e Língua Portuguesa, 1981.

BROGGIO, P. Evangelizzare il mondo: le missioni della Compagnia di Gesù tra Europa e America (secoli XVI-XVII). Roma: Carocci, 2004. 
CABRAL, L. G. V. C. P. Vieira pregador. Porto: José Frutuoso da Fonseca, 1901. v. 2. CANTEL, R. Les sermons de Vieira: étude du style. Paris: Hispano-Americanas, 1959. CARVALHO DA SILVA, P. J. A tristeza na cultura luso-brasileira: os sermões do padre Antonio Vieira. São Paulo: EDUC, 2000.

CHATELLIER, L. A religião dos pobres: as fontes do cristianismo moderno século XVI-XIX. Lisboa: Estampa, 1995.

CIDADE, H. Atividade política do padre Antonio Vieira. Lisboa: Independência, 1955. v. 14-15.

FLORENSKIJ, P. Il valore magico della parola. Milano: Medusa, 2001.

GRACIÁN, B. Arte de ingenio, Tratado de la Agudeza. Madrid: Cátedra, 1998.

HANSEN, J. A. Prefácio. In: PÉCORA, A. B. Teatro do sacramento: a unidade teológico-retórico-política dos sermões de Antonio Vieira. Campinas: Ed. da Unicamp; São Paulo: EDUSP, 1994. p. 15-36.

Sistemas doutrinários da representação nas obras de Antônio Vieira. In: AZEVEDO, S. M; COSTA RIBEIRO, V. (Org.). Vieira: vida e palavra. São Paulo: Loyola, 2008. p. 156-182.

HENRY, M. Eucaristia e fenomenologia nella riflessione filosofica contemporanea In: REALI, N. (Org.). Il mondo del sacramento: teologia e filosofia a confronto. Milano: Paoline, 2001. p. 125-133.

KOLVENBACH, P. H. Foli per Cristo: la sapienza di Maestro Ignazio. Roma: Borla, 1999. LEITE, S. História da Companhia de Jesus no Brasil. Lisboa: Portugalia; Rio de Janeiro: Civilizacão Brasileira, 1938-1950. v. 4.

LINS, I. Aspectos do Padre Antonio Vieira. Rio de Janeiro: São José, 1956.

LISBOA, J. F. Vida do Padre Antonio Vieira. São Paulo: Jackson, 1952.

LOBO, F. A. Memória histórica e critica acerca do Padre António Vieira e das suas Obras. Coimbra: Imprensa da Universidade, 1897.

MAJORANA, B. Il pulpito e l'attrice il teatro nella predicazione di Paolo Segneri en fantasmi femminili nel castello dell'incoscio maschile: atti del convegno internazionale. Genova: Costa \& Nolan, 1996. 
MARTINS DE ASSIS, R. A fineza do amor nos sermões do mandato do Padre Antonio Vieira. In: MASSIMI, M.; CARVALHO DA SILVA, P. J (Org.). Os olhos vêem pelo coração: conhecimento psicológico das paixões na história da cultura brasileira dos séculos XVI a XVII. Ribeirão Preto: Holos, 2001. p. 65-67.

MASSIMI, M. Identidade, tempo, profecia na visão do Padre Antonio Vieira. Memorandum: Memória e História em Psicologia, v. 1, n. 1, 2003. Disponível em: <http://www.fafich.ufmg.br/ memorandum>. Acesso em: 22 out. 2009.

. Palavras, almas e corpos no Brasil colonial. São Paulo: Loyola, 2005.

MASSIMI, M.; CARVALHO DA SILVA, P. J. (Org.). Os olhos vêem pelo coração: conhecimento psicológico das paixões na história da cultura brasileira dos séculos XVI a XVII. Ribeirão Preto: Holos, 2001.

MENDES, M. V. A oratória barroca de Vieira. Lisboa: Caminho, 1989.

PALACÍN, L. G. Vieira: entre o reino imperfeito e o reino consumado. São Paulo: Loyola, 1998.

PÉCORA, A. B. Teatro do sacramento: a unidade teológico-retórico-política dos sermões de Antonio Vieira. Campinas: Unicamp; São Paulo: EDUSP, 1994.

PÉCORA, A. B. Introdução: sermões, o modelo sacramental. In: VIEIRA, A. Sermões. São Paulo: Hedra, 2000. Tomo I, p. 25.

RAIMONDI, E. Trattatisti e narratori del Seicento. Milano-Napoli: Riccardo Ricciardi, 1960.

ROMANO, A.; FABRE, P. A. Presentation. Les jésuites dans le monde moderne: nouvelles approches. Reveu de Synthèse, n. 2/3, p. 247-260, 1999.

SARAIVA, A. J. O discurso engenhoso. São Paulo: Perspectiva, 1980.

VIEIRA A. Sermões. Erechim: Edelbra, 1998. 12 v.

Recebido: 15/11/2009

Received: 11/15/2009

Aprovado: $10 / 03 / 2010$

Approved: 03/10/2010 